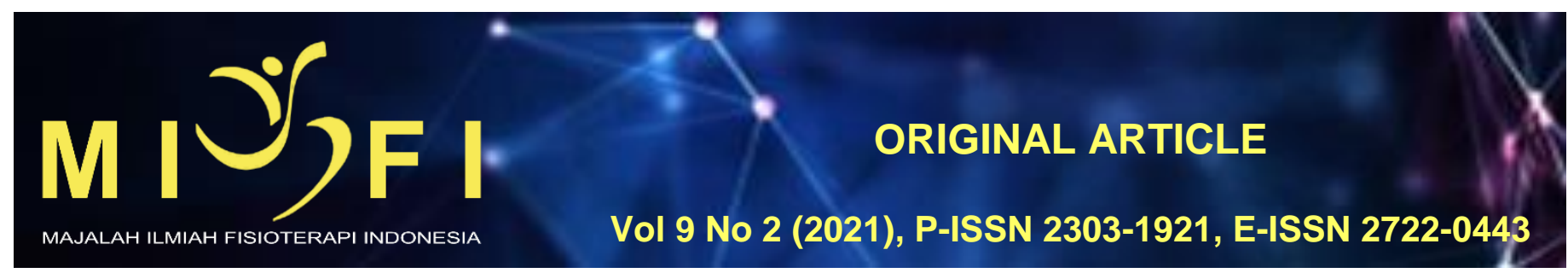

\title{
STUDI TENTANG TINGKAT STRES, KUALITAS TIDUR DAN INDEKS MASSA TUBUH MAHASISWI TINGKAT AKHIR FAKULTAS KEDOKTERAN UNIVERSITAS UDAYANA
}

\section{Ni Luh Gede Puji Andini' ${ }^{1}$, Made Hendra Satria Nugraha ${ }^{2}$, M. Widnyana ${ }^{3}$, I Made Muliarta ${ }^{4}$}

${ }^{1}$ Program Studi Sarjana Fisioterapi dan Profesi Fisioterapi, Fakultas Kedokteran Universitas Udayana, Denpasar, Bali

${ }^{2,3}$ Departemen Fisioterapi, Fakultas Kedokteran Universitas Udayana, Denpasar, Bali

${ }^{4}$ Departemen Ilmu Faal, Fakultas Kedokteran Universitas Udayana, Denpasar, Bali

\section{puji.andini18@gmail.com}

\begin{abstract}
ABSTRAK
Mahasiswi yang sedang memasuki akhir semester akan dihadapkan dengan berbagai tuntutan akademik yang harus diselesaikan dengan waktu yang diberikan dan penyelesain skripsi pada akhir semester. Mahasiswi yang menghadapi hal tersebut akan mengalami stres dan mengalami perubahan pada kualitas tidur yang dapat mempengaruhi indeks massa tubuh seseorang. Perubahan pola hidup tersebut seringkali menjadi beban tambahan selain beban akademik bagi mahasiswi. Penelitian ini bertujuan untuk mengetahui hubungan tingkat stress dan kualitas tidur terhadap indeks massa tubuh mahasiswi tingkat akhir Fakultas Kedokteran Universitas Udayana. Penelitian ini merupakan penelitian observasional analitik dengan rancangan cross sectional dengan Teknik pengambilan sampel yaitu simple random sampling dengan jumlah sampel 61 orang. Pengumpulan data dilakukan dengan mengukur tingkat stres dengan menggunakan kuisioner DASS42 (Depression Anxiety Stres Scale 42), mengukur kualitas tidur dengan menggunakan kuisioner PSQI (The Pittsburgh Sleep Quality Index) dan mengukur IMT. Uji hipotesis yang digunakan adalah chi-square untuk menganalisis hubungan tingkat stres dengan IMT diperoleh nilai $p$ sebesar 0,740 sehingga nilai $p>0,005$, kualitas tidur dengan IMT diperoleh nilai $p$ sebesar 0,200 sehingga $p>0,005$ dan stres dengan kualitas tidur diperoleh nilai $p$ sebesar 0,001 sehingga nilai $p<0,001$. Berdasarkan hasil penelitian dan uji statistik tersebut, maka disimpulkan bahwa tidak terdapat hubungan yang signifikan antara stres dan kualitas tidur terhadap indeks massa tubuh dan terdapat hubungan yang signifikan antara tingkat stres terhadap kualitas tidur mahasisiwi tingkat akhir Fakultas Kedokteran Universitas Udayana.
\end{abstract}

Kata kunci: Mahasiswi, Stres, Kulitas Tidur, IMT

\section{THE STUDY ON STRESS LEVEL, SLEEP QUALITY AND BODY MASS INDEX ON FINAL YEAR STUDENTS IN FACULTY OF MEDICINE UDAYANA UNIVERSITY}

\section{ABSTRACT}

Students who are entering the end of the semester will be faced with various academic condition that must be completed with the time given and completion of the thesis at the end of the semester. Students who face this will experience stress and experience changes in the quality of sleep which can affect a person's body mass index. Changes in lifestyle are often an additional burden in addition to the academic burden for female students. This study aims to determine the relationship between stress levels and sleep quality towards the final year female body mass index of the Faculty of Medicine, Udayana University. This study is an observational analytic study with a cross-sectional design. Sampling technique were used simple random sampling with a sample of 61 people. Data collection was done by measuring stress levels using the DASS42 questionnaire (Depression Anxiety Stress Scale 42), measuring sleep quality by using the PSQI questionnaire (The Pittsburgh Sleep Quality Index) and measuring BMI. Hypothesis testing uses chisquare to analyze the relationship between stress levels and BMI obtained a $p$-value of 0.740 so that the value of $p>$ 0.005 , the quality of sleep with BMI obtained a p-value of 0.200 so that $p>0.005$ and stress with sleep quality obtained a p-value of 0.001 so $p$-value $<0.001$. Based on the results of the study and statistical tests, it was concluded that there was no significant relationship between stress and sleep quality on body mass index and there was a significant relationship between stress levels on the quality of the final level of sleep in the Udayana University Faculty of Medicine Keywords: Student, Stress, Sleep-quality, BMI

\section{PENDAHULUAN}

Mahasiswi adalah individu yang belajar di bangku perkuliahan dengan mengambil jurusan yang diminati untuk mengembangkan bakatnya. Mahasiswi memiliki tanggung jawab moral terhadap diri. Mahasiswi memiliki peran sebagai generasi penerus bangsa yang sangat diharapkan dengan mempunyai kemampuan, keterampilan, serta akhlak mulia untuk menjadi calon pemimpin bangsa di masa depan. ${ }^{1}$

Mahasiswi merupakan seseorang yang digolongkan pada tahap perkembangan usia 20-23 tahun. Tahap ini dikategorikan masa remaja akhir sampai masa dewasa awal dan dilihat dari segi perkembangannya. Seiring dengan perkembangan zaman dan kemajuan teknologi membuat mahasiswi dituntut harus mampu menyelesaikan masalah akademis. ${ }^{2}$ Mahasiswi yang mengalami stres akademik meningkat setiap semesternya. Stres yang paling umum dialami oleh mahasiswi merupakan stres akademik. Stres akademik diartikan sebagai suatukeadaan individu yang mengalami 
tekanan hasil persepsi dan penilaian tentang stressor akademik, yang berhubungan dengan ilmu pengetahuan dan pendidikan di perguruan tinggi. ${ }^{3}$ Mahasiswi mengalami stress sebagai tuntutan kehidupan akademik yang harus dijalani, termasuk aktivitas diluar akademik diantaranya bersosialisasi dan menyesuaikan diri dengan teman sesama mahasiswi dimana memiliki karakteristik dan latar belakang yang berbeda, mengembangkan bakat dan minat melalui kegiatan kegiatan non akademis, dan bekerja sama untuk menambah uang saku. ${ }^{4}$ Kondisi - kondisi tersebut menjadi stressor bagi mahasiswi. Perubahan pola hidup yang kompleks tersebut seringkali menjadi beban tambahan selain beban akademik bagi mahasiswi. ${ }^{5}$

Stres ialah kondisi dimana seseorang mengalami tuntutan emosi secara berlebihan. Keadaan ini dapat mengakibatkan munculnya banyak gejala seperti depresi, kelelahan kronis, mudah marah, gelisah, impotensi, dan kualitas tidur yang rendah. ${ }^{6}$ Tuntutan akademik yang dihadapi seseorang akan memicu stressor. Stressor berasal dari dalam diri maupun luar diri mahasiswi. ${ }^{7}$ Stres dibagi menjadi dua yaitu stres yang merugikan , merusak, atau bersifat negatif disebut dengan distress sedangkan stres yang bersifat positif dan membangun atau menguntungkan disebut dengan eustress. ${ }^{8}$ Stres dibagi menjadi dua yaitu stres yang merugikan , merusak, atau bersifat negatif disebut dengan distress sedangkan stres yang bersifat positif dan membangun atau menguntungkan disebut dengan eustress. ${ }^{9}$ Stres dapat menimbulkan dampak yang baik atau positif. Namun, ada juga yang berdampak buruk atau negatif. Stres yang berdampak pada hal yang baik atau positif ialah stres yang meningkatkan kualitas belajar dan berpikir sedangkan stres pada hal yang buruk atau negatif menimbulkan gejala seperti gejala fisiologis, psikologis, interpersonal, kognitif, dan organisasional. ${ }^{10}$ Gejala fisiologis yang ditimbulkan seperti sakit kepala, sembelit, diare, sakit pinggang, otot tegang pada tengkuk, maag, kelelahan, sakit perut, tekanan darah tinggi, hilangnya selera makan, susah tidur, dan kehilangan semangat. Mahasiswi menyelesaikan akademiknya dihadapkan pada kondisi ujian, kondisi adaptasi terhadap perubahan kehidupan perkuliahan, kondisi perbedaan bahasa yang biasa digunakan dan pada akhirnya mahasiswi dihadapkan untuk menyelesaikan skripsi dimana mahasiwa sulit mencari referensi dan keterbatasan waktu penelitian, sehingga berpengaruh terhadap kualitas tidur. ${ }^{11}$

Tidur merupakan kebutuhan dasar bagi setiap individu. Tidur merupakan aktivitas otak yang diistirahatkan dimana kemampuan tubuh individu tidak dapat merespon stimulus yang tidak begitu penting. ${ }^{12}$ Tidur berfungsi untuk tubuh untuk melepaskan hormon pertumbuhan dimana berperan dalam memperbaiki dan memperbaharui sel epitel dan sel otak. Otak yang menyaring informasi yang telah direkam selama sehari dan mendapat asupan oksigen serta aliran darah serebral menjadi optimal selama tidur dan untuk menyimpan memori yang didapat seharian serta pemulihan fungsi kognitif. Fisiologis tidur merupakan kegiatan tidur yang melibatkan hubungan mekanisme serebral secara bergantian untuk mengaktifkan dan menekan pusat otak untuk dapat tertidur dan bangun. Pengaturan mekanisme tidur dan bangun dipengaruhi oleh sistem aktivasi retikuler (SAR). SAR terletak dibatang otak teratas yang terdiri dari sel khusus untuk mempertahankan kewaspadaan dan terjaga. Bila aktivitas SAR meningkat makan seseorang tersebut dalam keadaan sadar. Jika, SAR menurun maka seseorang dalam keadaan tidur. Aktivitas SAR sangat dipengaruhi oleh aktifitas neurotransmitter. Aktivitas SAR juga dipengaruhi oleh beberapa hormon seperti ACTH, TSH, dan LH. Mekanisme serebral secara bergantian mengaktifkan dan menekan pusat otak agar dapat tertidur dan bangun. ${ }^{13}$ Tahapan tidur diidentifikasi melalui pola electroencephalograph (EEG), pergerakan mata, dan aktivitas otot. Tahapan tidur dapat dibagi dalam dua kategori yaitu Non-rapid Eye Movement (NREM) dan Rapid Eye Movement (REM). ${ }^{14}$ Fungsi tidur pada individu juga bertujuan agar merelaksasikan otot sehingga laju metabolik basal menurun dimana saat tidur akan menyimpan lebih banyak energi. Individu yang tidurnya kurang akan menyebabkan perubahan fungsi tubuh, baik kemampuan motorik, memori, serta keseimbangan. Tidur dapat membantu perkembangan perilaku individu yang mengalami masalah pada tahap REM (Rapid Eye Movement) akan merasa bingung. ${ }^{15}$

IMT merupakan cara sederhana untuk memantau gizi orang dewasa. Berat badan yang kurang atau lebih beresiko terserang penyakit infeksi. Berat badan yang berlebihan beresiko terserang penyakit degeneratif. IMT merupakan rumus matematis dimana berat badan (dalam kilogram) dibagi tinggi badan (dalam meter kuadrat). ${ }^{16}$

Mahasiswi yang sedang mengalami tingkat stres dalam menyelesaikan skripsi dapat mengalami gangguan tidur sehingga dampak dari stres yang dialami dan kualitas tidur yang menurun akan mempengaruhi Indeks Massa Tubuh mahasiswi tersebut. Apabila ini berlangsung lama berdampak dengan hitungan IMT yang berlebih atau kurang akan menimbulkan masalah. Oleh karena itu, penulis akan melakukan penelitian untuk mengetahui apakah terdapat hubungan tingkat stres dan kualitas tidur terhadap indeks massa tubuh.

\section{METODE}

Penelitian ini menggunakan desain penelitian observasional analitik dengan pendekatan cross sectional yang telah dilakukan pada bulan April 2019, nomor :239/UN14.2.2.V/PD/2019 di Fakultas Kedokteran Universitas Udayana. Penelitian ini telah disetujui oleh Komite Etik Penelitian Fakultas Kedokteran Udayana/ Rumah Sakit Umum Pusat Sanglah Denpasar tertanggal 01 April 2019. Teknik yang digunakan untuk penentuan sampel penelitian adalah simple random sampling. Total sampel penelitian ini sebanyak 61 orang yang didapat melalui kriteria inklusi yaitu mahasiswi dengan usia $21-23$ tahun. Sementara itu kriteria eksklusi yang diterapkan adalah sampel tidak bersedia berpartisipasi dalam penelitian sedang melakukan program diet.

Varibel independen pada penelitian ini adalah stres dan kualitas tidur sementara IMT dan kualitas tidur merupakan variabel dependen. Pertama, sampel akan diminta persetujuan untuk berpartisipasi dalam penelitian dengan mengisi informed consent. Selanjutnya, sampel akan wawancara menggunakan kuesioner Depression, Anxiety and Stress Scalse 42 untuk mengukur stres sampel dan kuesioner International Physical Activity Questionnaire - Short Form untuk mengetahui kualitas tidur sampel dan pengukuran IMT.

Software statistika digunakan untuk melakukan analisis data. Hasil data yang telah diperoleh selanjutnya dianalisis menggunakan software IBM SPSS Statistics 20 dan analisis bivariat menggunakan Uji Statistik Chi-Square test. 
HASIL

Penelitian ini mendata 61 orang mahasiswi dari program studi Fisioterapi dengan rentan usia 21-23 tahun. Berikut adalah table analisis data penelitian.

Tabel 1. Distribusi Frekuensi Karakteristik Responden

\begin{tabular}{lcc}
\hline Variabel & Frekuensi (n) & Persentase (\%) \\
\hline Usia & & \\
21 & 17 & 27,9 \\
22 & 14 & 23,0 \\
23 & 30 & 49,2 \\
IMT & & \\
$\quad$ Underweight & 1 & 1,6 \\
$\quad$ Normal & 27 & 44,3 \\
$\quad$ Overweight & 15 & 24,6 \\
Obesitas 1 & 13 & 21,3 \\
Obesitas 2 & 3 & 8,2 \\
Stres & & \\
Ringan & 32 & 52,2 \\
Sedang & 27 & 44,3 \\
Berat & 2 & 3,3 \\
Kualitas Tidur & & \\
Baik & 22 & 36,1 \\
Buruk & 39 & 63,9 \\
\hline maka diketahui bahwa responden
\end{tabular}

Berdasarkan data Tabel 1. maka diketahui bahwa responden terbanyak adalah mahasiswi berusia 23 tahun yaitu sebanyak 30 orang $(49,2 \%)$, diikuti oleh mahasiswi berusia 21 tahun sebanyak 17 orang $(27,9 \%)$, dan mahasiswi berusia bahwa mayoritas responden memiliki IMT normal yaitu sebanyak 27 orang $(44,3 \%)$, diikuti kategori underweight memiliki nilai terendah yaitu sebanyak 1 orang $(1,6 \%)$, kategori overweight yaitu sebanyak 15 orang $(24,6 \%)$, kategori obesitas 1 yaitu sebanyak 13 orang $(21,3 \%)$ sedangkan kategori obesitas 2 yaitu 3 sebanyak 3 orang $(8,2 \%)$. Dilihat dari sebaran kuisioner stres pada mahasisiwi tingkat akhir program studi Fisioterapi FK Unud terdapat kategori stres ringan sebanyak 32 orang $(52,2 \%)$, kategori stres sedang yaitu sebanyak 27 orang $(44,3 \%)$, dan kategori stres berat yaitu sebanyak 2 orang $(3,3 \%)$. Menurut data kualitas tidur responden yang terbagi menjadi kategori baik dan buruk, terlihat kategori buruk mendominasi sebanyak 39 orang $(63,9 \%)$, sedangkan kategori baik yaitu 22 orang $(36,1 \%)$.

Hasil dari analisis univariat adalah berupa karakteristik sampel. Dalam penelitian ini karakteristik dari sampel adalah tingkat stres, kualitas tidur,IMT, stres dengan IMT, kualitas tidur dengan IMT, dan stres dengan kualitas tidur.

Tabel 2. Karakteristik Sampel berdasarkan tingkat stres dengan IMT

\begin{tabular}{cccc}
\hline \multirow{2}{*}{ Stres } & \multicolumn{2}{c}{ IMT } & \multirow{2}{*}{ Total } \\
\cline { 2 - 3 } & Normal & Abnormal & \\
\hline Ringan & $19(54,3 \%)$ & $16(45,7 \%)$ & $35(52,5 \%)$ \\
Sedang & $13(50 \%)$ & $13(50 \%)$ & $26(47,5 \%)$ \\
Total & $32(104,3 \%)$ & $29(95,7 \%)$ & $61(100,0 \%)$ \\
\hline
\end{tabular}

Pada tabel 2. menunjukkan bahwa responden terbanyak memiliki tingkat stress ringan dengan IMT normal yang berjumlah sebesar 19 orang, diikuti oleh tingkat stress ringan dengan IMT abnormal sebnyak 16 orang, sedangkan pada tingkat stress sedang baik IMT normal maupun abnormal memiliki jumlah sample yang sama sebesar 13 orang pada mahasiswi Fisioterapi FK Udayana. Melalui uji chi Square test didapat nilai P sebesar 0.740 yang menunjukkan bahwa tidak terdapat hubungan antara tingkat stress terhapat IMT pada mahasiswi Fisioterapi FK Udayana $(P>0.05)$. Berdasarkan uji statistik dapat ditemukan bahwa tidak adanya hubungan yang signifikan antara tingkat stres terhadap indeks massa tubuh pada mahasiswi program studi Fisioterapi FK Unud.

Tabel 3. Karakteristik sampel berdasarkan hubungan kualitas tidur dengan IMT

\begin{tabular}{cccc}
\hline \multirow{2}{*}{ Kualitas Tidur } & \multicolumn{2}{c}{ IMT } & \multirow{2}{*}{ Total } \\
\cline { 2 - 3 } & Normal & Abnormal & \\
\hline Baik & $15(42,9 \%)$ & $20(57,1 \%)$ & $35(36,1 \%)$ \\
Buruk & $7(26,9 \%)$ & $19(73,1 \%)$ & $26(63,9 \%)$ \\
Total & $22(68,18 \%)$ & $39(130,2 \%)$ & $61(100,0 \%)$ \\
\hline
\end{tabular}

Pada tabel 3. menunjukkan bahwa responden terbanyak memiliki Kualitas tidur baik dengan IMT normal yang berjumlah sebesar 15 orang, diikuti oleh dengan kualitas tidur ringan dengan IMT abnormal sebnyak 20 orang, sedangkan pada kualitas tidur buruk dengat IMT normal kualitas tidur buruk dan kualitas tidur buruk dengan IMT abnormal 19 orang pada mahasiswi Fisioterapi FK Udayana. Melalui uji Chi Square test didapat nilai P sebesar 0.200 yang menunjukkan bahwa tidak terdapat hubungan yang signifikan kualitas tidur terdapat IMT pada mahasiswi Fisioterapi FK Udayana $(P>0.05)$. Berdasarkan uji statistik dapat ditemukan bahwa tidak adanya hubungan yang signifikan antara kualitas tidur terhadap indeks massa tubuh pada mahasiswi program studi Fisioterapi FK Unud. 
Tabel 4. Karakteristik sampel berdasarkan hubungan stres dengan kualitas tidur

\begin{tabular}{cccc}
\hline \multirow{2}{*}{ Stres } & \multicolumn{2}{c}{ Kualitas Tidur } & \multirow{2}{*}{ Total } \\
\cline { 2 - 3 } & Baik & Buruk & \\
\hline Ringan & $18(81,8 \%)$ & $4(18,2 \%)$ & $22(52,2 \%)$ \\
Sedang & $14(35,9 \%)$ & $25(64,1 \%)$ & $39(47,5 \%)$ \\
Total & $32(117,7 \%)$ & $29(82,3 \%)$ & $61(100,0 \%)$ \\
\hline
\end{tabular}

Pada Tabel 4. menunjukkan bahwa responden terbanyak memiliki stress ringan dengan Kualitas tidur baik yang berjumlah sebesar 18 orang, diikuti oleh dengan stress dengan kualitas tidur buruk sebnyak 4 orang, sedangkan pada stress dengan kualitas tidur buruk sebanyak 14 orang dan stress dengan kualitas tidur buruk sebanyak 25 orang mahasiswi Fisioterapi FK Udayana. Hasil penelitian setelah dilakukan uji Chi Square Test mendapatkan nilai p sebesar 0,001 sehingga nilai $p<0,005$. Berdasarkan uji statistik dapat ditemukan bahwa adanya hubungan yang signifikan antara tingkat stress terhadap kualitas tidur pada mahasiswi program studi Fisioterapi FK Unud.

\section{DISKUSI}

\section{Hubungan Tingkat Stres Dengan IMT}

Berdasarkan hasil pengujian data dengan Chi Square Test pada jumlah data penelitian sebanyak 61 responden, ditemukan nilai $p$ yaitu sebesar 0,740 pada hasil analisis hubungan stres dengan IMT sehingga nilai $p>0,005$. Sebagaimana dasar pengambilan keputusan yang telah ditetapkan maka dalam penelitian ini berarti Ho diterima dan Ha ditolak, sehingga dapat disimpulkan bahwa tidak ada hubungan antara stres dengan IMT pada mahasiswi tingkat akhir Di FK Unud.

Hasil ini serupa dengan penelitian Resti pada tahun 2012 bahwa tidak terdapat hubungan antara stres dengan IMT. Potter and Perry (2010) menjelaskan bahwa stres yang dialami setiap individu hanya dalam hitungan hari atau sementara sehingga tidak adanya hubungan stres dengan IMT.17

Menurut Mayoral 2006 strategi untuk memecahkan masalah-masalah hidup, mengurangi dan mengatasi stress adalah Koping. Terdapat 2 bentuk strategi Koping, yaitu; Emotion-focused coping dan problem-focused coping. Emotion-focused coping adalah cara mengalihkan fokus dan perhatian dari sumber masalah, misalnya dengan mencurahkan perasaan atau menuliskan tentang masalah-masalah yang dihadapinya, meditasi, ataupun dengan berdoa. Problem-focused coping dapat diterapkan karena stres berasal dari pekerjaan atau tekanan saat sedang mencapai suatu tujuan seperti dalam menyelesaikan tugas. Dalam menerapkan problem-focused coping individu memiliki kemampuan dalam memecahkan masalah, manajemen waktu yang baik, dengan adanya dukungan sosial untuk mengatasi masalah yang diperlukan adalah keyakinan dari diri sendiri untuk menilai dan menimbang apakah situasi tersebut dapat dikendalikan. Perbedaan strategi stres disetiap individu tidak semua berdampak pada peningkatan pola makan dan berimbas pada peningkatan indeks massa tubuh. ${ }^{18}$

\section{Hubungan Tingkat Kualitas Tidur Dengan IMT}

Berdasarkan hasil pengujian data dengan Chi Square Test pada jumlah data penelitian sebanyak 61 responden, ditemukan nilai $p$ yaitu sebesar 0,2 pada hasil analisis hubungan kualitas tidur dengan IMT sehingga nilai $p>0,005$. Sebagaimana dasar pengambilan keputusan yang telah ditetapkan maka dalam penelitian ini berarti Ho diterima dan Ha ditolak, sehingga dapat disimpulkan bahwa tidak ada hubungan antara kualitas tidur dengan IMT pada mahasiswi tingkat akhir Di FK Unud.

Menurut Dwi Ningrum 2011 Pada usia dewasa muda irama sirkadian tubuh akan menyesuaikan jam tidur dengan aktivitas yang dilakukan setiap hari, pola tidur yang berubah-ubah disebabkan oleh kesibukan dan tuntutan pekerjaan. Jam tidur yang berubah-ubah pada dewasa muda tidak mempengaruhi pada pola makan seseorang. Sedangkan pola makan sendiri memiliki hubungan yang erat dengan IMT. Pola makan yang baik maka indeks massa tubuh yang didapatkan normal sebaliknya dengan pola makan yang kurang maka indeks massa tubuh yang didapatkan kurus, perbedaan pola makan tiap individu inilah yang menyebabkan perbedaan IMT masing-masing individu. ${ }^{19}$

Menurut Gleen 2010 bahwa semakin banyak tuntutan dan tekanan pada mahasiswa tingkat akhir yang sedang menyusun skripsi dapat memperlemah dalam memecahkan masalah dan tuntutan-tuntutan sehingga dapat mengakibatkan tidur yang tidak sehat atau gelisah. ${ }^{20}$

Prasadja 2019 mengunggkapkan bahwa kualitas tidur buruk disebabkan oleh aktivitas sosial, karena pada usia dewasa muda seseorang sedang berada di puncak keaktifan dalam aktifitas sosial. Selain faktor aktivitas sosial, faktor elektronik juga sangat mempengaruhi kualitas tidur seseorang, seperti akses internet, peralatan elektronik yang ada di kamar tidur seperti televisi, gadget, dan komputer. ${ }^{21}$

Pratiwi 2011 mengunggkapkan yang mempengaruhi pola makan pada individu diantaranya pola konsumsi, faktor aktivitas, dan faktor karakteristik orang tua. Dari semua faktor tersebut kualitas tidur tidak mempengaruhi pola makan, sehingga dapat disimpulkan kualitas tidur tidak secara langsung mempengaruhi IMT. ${ }^{22}$

\section{Hubungan Tingkat Stres dengan Kualitas Tidur}

Berdasarkan hasil pengujian data dengan Chi Square Test pada jumlah data penelitian sebanyak 61 responden, ditemukan nilai $p$ yaitu sebesar 0,001 pada hasil analisis hubungan tingkat stres dengan kualitas tidur sehingga nilai $p<0,005$. Sebagaimana dasar pengambilan keputusan yang telah ditetapkan maka dalam penelitian ini berarti Ho ditolak dan Ha diterima, sehingga dapat disimpulkan bahwa ada hubungan antara kualitas tidur dengan IMT pada mahasiswi tingkat akhir Di FK Unud.

Menurut Abdulghani 2011 tingkat stres merupakan faktor resiko terhadap kualitas tidur buruk. Kecendrungan stres sering terjadi pada mahasiswa tingkat akhir dimana ia diberikan tugas akhir kuliah berupa skripsi, yang mana dalam mengerjakannya sering sekali mahasiswa menghadapi berbagai macam kendala yang nantinya akan 
berpengaruh terhadap kualitas tidurnya, sehingga mengakibatkan mahasiswa tersebut memiliki kualitas tidur yang buruk. Dimana mahasiswa yang mengalami stres akan terus berfikir terhadap stresor yang dihadapinya sehingga dapat mengakibatkan dia tidak bisa tidur dengan tenang. ${ }^{23}$

Menurut penelitian National Safety Counsil 2004 Stres adalah ketidakmampuan mengatasi ancaman yang dihadapi oleh mental, fisik, emosional dan spriritual yang pada suatu saat dapat mempengaruhi kesehatan fisik manusia tersebut. Stres normal merupakan reaksi alamiah yang berguna, karena stres akan mendorong kemampuan seseorang untuk mengatasi kesulitan kehidupan. Tekanan stres yang besar hingga melampaui daya tahan individu, maka akan menimbulkan gejala-gejala seperti sakit kepala, mudah marah dan kesulitan untuk tidur. ${ }^{24}$

\section{SIMPULAN}

Berdasarkan hasil penelitian yang telah dilakukan, maka dapat disimpulkan bahwa

1. Tidak terdapat hubungan $(p=0,740)$ antara tingkat stres dan IMT pada mahasiswi program studi Fisioterapi FK Unud.

2. Tidak terdapat hubungan $(p=0,200)$ antara kualitas tidur dengan IMT pada mahasiswi program studi Fisioterapi FK Unud

3. Terdapat hubungan yang $(p=0,001)$ antara stres dengan kualitas tidur pada mahasiswi program studi Fisioterapi FK Unud.

\section{DAFTAR PUSTAKA}

1. Abdulghani, H.M. 2008. Stress and depression among medical students: A cross section study at medical college in Saudi Arabia. Pak J Med Sci, 24(1):12-27.

2. Delaune dan Ladner. 2002. Fundamental of nursing standarts \& practice second edition. USA: Delmar.

3. Dewe, P. J., O'Driscoll, M. P., dan Cooper, C. L. 2012. Theories of psychological stress at work. In Gatchel, R. J. \& I. Z. Schultz, I. Z. (eds.) Handbooks in health, work, and disability. USA: Springer. (pp. 23-38)

4. Gaultney, J.F. 2010. The prevalence of sleep disorders in college tudent: impact on academic performance. Journal of American College Health. Vol. 59, No. 2.

5. Yusuf, S. 2012. Psikologi Perkembangan Anak dan Remaja. Bandung: Remaja Rosdakarya.

6. Mayoral, L 2006. Exam stress, depression, social support, and sleep disturbance. ProQuest Disertations \& Theses (PQDT) pg.n/a.

7. Allen, L.V., Popovich, N.G., \& Ansel, H.C. 2011. Ansel's Dossage Forms and Drug Delivery Systems, 9th Ed. Lippinkott Williams \& Wilkins. Philadelphia. 225-256

8. Davidson, G.C, 2010, psikologi abnormal. Jakarta : PT Rajagrafindo permai.

9. Govaerst, S. \& Gregoire, J. Stressful academic situations: Study on appraisal variables in adolescence. British Journal of Clinical Psychology. 2004.

10. Gaultney, J.F. 2010. The prevalence of sleep disorders in college tudent: impact on academic performance. Journal of American College Health. Vol. 59, No. 2.

11. Iswanto.2007. Pola Hidup Sehat Dalam Keluarga.Jakarta: Sunda Kelapa Pustaka.

12. Potter, P.A, dan Perry, A.G.2010.Buku Ajar Fundamental Keperawatan : Konsep, Proses, dan Praktik.Edisi 4.Volume 2.Alih Bahasa : Renata Komalasari,dkk.Jakarta:EGC.

13. Prasadja, A. 2009. Ayo bangun dengan bugar karena tidur yang benar. Jakarta: Penerbit Hikmah.

14. Richard L. 2010. Era baru manajemen, Edisi 9, Buku 2, Salemba Empat, Jakarta.

15. Rafidah, Ida dan Arief Wibowo. 2012. Pengaruh Dukungan Suami Terhadap Kepatuhan Akseptor Melakukan KB Suntik. Jurnal Biometrika Dan Kependudukan,(1): 73. Surabaya: Departemen Biostatistika dan Kependudukan Fakultas Kesehatan Masyarakat Iniversitas Airlangga.

16. Safari, Eka N, Triantoro dan Saputra.2012 Manajemen Emosi. Jakarta : Bumi Aksara. 2012; 54-55.

17. National Safety Counsil. 2004. Manajemen Stress. Jakarta: EGC

18. Sukamulja dan Sukmawati. 2004, "Good Corporate Governance di Sektor Keuangan: Dampak Good Corporate Governance Terhadap Kinerja Keuangan".

19. Syarif, S, Kamil EA, dan Mansour A. stres and coping strategies among medical students in Basrah. Medical Journal of Basrah University. 2007 : (25); 28-32.

20. Suzanne, Cludy Smeltzer, dan Brenda Glyon Bare. 2008. Keperawatan Medikal Bedah 2, Edisi 8. Jakarta : EGC.

21. Tirta, M.P.L.K. 2006. Status Stres Psikososial Dan Hubungannya Dengan Status Gizi Siswa SMP Stella Duce 1 Yogyakarta. Jurnal Gzi Klinik Indonesia, Volume 6, No 3. Maret 2010.

22. The Lancet. 2006. Global childhood malnutrition. The Lancet, Volume 367, Issue 9521, Page 1459,6 May 2006 doi:10.1016/S0140-6736(06)68620-0.

23. Wang, J., Korczykowski, M., Rao, H., Fan, Y., Pluta, J., Gur, R. C.,\& Detre, J. A. 2007. Gender difference in neural response to psychological stres. Social cognitive and affective neuroscience, 2(3), 227-239.

24. Yusuf, S. 2012. Psikologi Perkembangan Anak dan Remaja. Bandung: Remaja Rosdakarya. 